\title{
Studies of the absorbance peak on the N719 dye influence by combination between Cadmium Selenide (CdSe)QDs and Zinc Sulfide(ZnS)QDs
} \author{
Mohamad Taib ${ }^{1,2}$ Ab Malik Marwan Ali ${ }^{1}$, and Rosnah Zakaria ${ }^{1,2, *}$ \\ ${ }^{1}$ Faculty of Applied Sciences, Universiti Teknologi MARA, 40450 Shah Alam, Selangor, Malaysia \\ ${ }^{2}$ Institute of Science, Universiti Teknologi MARA, 40450 Shah Alam, Selangor, Malaysia \\ ${ }^{3}$ Faculty of Art and Design, Universiti Teknologi MARA, 40450 Shah Alam, Selangor, Malaysia \\ ${ }^{4}$ Faculty of Defence Science \& Technology, Universiti Pertahanan Nasional Malaysia, 57000
}

Mohammad Azren Saad ${ }^{1, *}$, Noor Syafiqah Samsi ${ }^{1}$, Oskar Hasdinor Hassan ${ }^{3}$, Muhd Zu Azhan Yahya ${ }^{2,4}$, Mohamad Fariz

\begin{abstract}
The absorption rate of the photoanode can be influenced by the combination between the difference semiconductor quantum dot sensitizer. Six samples were prepared with difference weight percent (wt $\%$ ) of $\mathrm{ZnS}$ from $0 \%$ to $50 \%$ and constant $\mathrm{wt} \%$ of CdSe which then will be called as semiconductor QDs were immersed in $0.5 \mathrm{mM}$ of $\mathrm{N} 719$ dye. The purity of $\mathrm{ZnS}$ powder and CdSe powder was determined using $\mathrm{x}$-ray diffraction (XRD).The ultraviolet-visible spectrophotometry (Uv-Vis) use to investigate the absorption spectrum and absorbance peak of this sample. $50 \mathrm{wt} \%$ of $\mathrm{ZnS}$ is the best composition to increase the absorbance peak of the photoanode. The Cyclic voltammetry (CV) of varying wt $\%$ of $\mathrm{ZnS}$, found that the 40 $\mathrm{wt} \%$ of $\mathrm{ZnS}$ is suitable combination for a DSSC's photoanode and produced the higher current.
\end{abstract}

\section{Introduction}

Nowadays people are looking for the artificial sources to replace the traditional source. Quantum - dot-sensitized solar cells (QDSSCs) is the most suitable artificial source to replace the traditional sources[1].The benefit using the QDSCs as the artificial source is low cost and the efficiencies boosted up to the traditional Shockley and Queisser limit of 30\%[3]. The only difference between the Dye-synthesis solar cell (DSSCs) compare to QDSCs is the replacement of organometallic or organic dye with the narrow band gap semiconductor material QD and the combination between QD and dye is called QDSCs. The most important part in the QDSCs is the photoanode, this part consists of sensitizers which are a semiconductor QD. The semiconductor QDs will be combined with the $\mathrm{TiO}_{2}$ and coated onto glass sustrate. The semiconductor quantum dot such as InAs, $\mathrm{CdSe}, \mathrm{CdS}, \mathrm{PbSe}$, and InP have a narrow band gap that is suitable to be used as the sensitized in the QDSCs [3]. The narrow bandgap will couse of easily electron transport when exposes to visible light and even though the light carries a low energy the emitted electron will travel through the $\mathrm{TiO} 2$ nanoparticle until it reaches anode, the electron produce current and energy to a device [4]. This electron will arrive at the cathode and move into the electrolyte to be sent back into the QDs in the photoanode [6]. QDs afford extremely optical properties and admirable electrical properties as compared to traditional organic dyes [3]. Furthermore, the various properties of semiconductor QDs make them attractive to take a part in the QDSSCs as a sensitizer. The high absorption coefficients make it suitable for the generation of multiple electrons carrier under high-energy excitation [5].

The high potential of semiconductor QDs sensitizer for light harvesting in the visible -light region, drawn much attention to be explored by the researcher [11]. Semiconductor QDs which is $\mathrm{CdSe} / \mathrm{ZnS}$ has higher conduction band compared to the $\mathrm{TiO}_{2}$ layer, this can increase the rate of electron injection of photon excited electrons into the photoanode. The band gap of $\mathrm{ZnS}$ is $3.6 \mathrm{eV}$, this will limit the absorption range below a wavelength of $344 \mathrm{~nm}$ and the band gap for the CdSe is $1.7 \mathrm{eV}$ [3], therefore the wavelength absorption that can be absorbed is below the $720 \mathrm{~nm}$. Because of the low conduction band edge of CdSe compare to $\mathrm{ZnS}$ and $\mathrm{TiO}_{2}$, the efficiency of injection electron could be less.

Light carries the source energy in the form of a photon, this energy will be permeated by a particle in the material [9]. If the particle absorbs the energy of light bigger than their band gap, this particle will emit electron out from their shell [12]. These studies were investigated the variation of absorption spectrum by the photoanode with the difference the weight percent of $\mathrm{ZnS} / \mathrm{CdSe}$.

\section{Methodology}

\subsection{Preparation of CdSe/ZnS solution}

The two main material are CdSe and $\mathrm{ZnS}$ purchased from Sigma Aldrich. Various wt $\%$ of the $\mathrm{ZnS}$, were mixed into

\footnotetext{
Corresponding author: azrensaad@yahoo.com.my
} 
CdSe QDs. 0.045 g ruthenium-based dye (N719) were dissolve in $9 \mathrm{~mL}$ of ethanol to produce $0.5 \mathrm{mM}$ of liquid N719

concentration $=($ number of mole $) /($ volume $)$

molar mass $=($ mass $) /($ number of mole $)$

Six samples of QDss were prepared with difference weight percent (wt\%) of $\mathrm{ZnS}$ from $0 \%$ to $50 \%$ and constant $10 \%$ of CdSe. The solution of $0.5 \mathrm{mM}$ of $\mathrm{N} 719$ was added. The samples were stirred for 24 hours using magnetic stirrer to get a homogenous solution. The mass of QDs $\mathrm{ZnS} / \mathrm{CdSe}$ powder for each sample were calculated using equation below:

Wcdse/zns $=(x(w n 719)) /(1-x))$

Where $x$ is the percentage of $\mathrm{ZnS} / \mathrm{CdSe}$

Table 1. Percentage of CdSe/ZnS QDs Prepared.

\begin{tabular}{|c|c|c|c|}
\hline Sample & $\begin{array}{c}\text { CdSe/Zns } \\
\text { QDs } \\
\text { composition } \\
(\text { wt\%) }\end{array}$ & $\begin{array}{c}\text { Mass of } \\
\text { N719dye } \\
\text { powder }\end{array}$ & $\begin{array}{c}\text { Mass of } \\
\text { CdSe/ ZnS } \\
\text { QDs powder } \\
\text { (g) }\end{array}$ \\
\hline A & 10 & 0.045 & 0.005 \\
\hline B & 20 & 0.045 & 0.011 \\
\hline C & 30 & 0.045 & 0.019 \\
\hline E & 40 & 0.045 & 0.030 \\
\hline
\end{tabular}

\section{2 preparation of photoanode}

Three steps of cleaning ITO glass using ultrasonic bath where the first step is using the distilled water then acetone and followed by ethanol. Then, the ITO glass was dried at $60^{\circ} \mathrm{C}$ for 21 hours. $\mathrm{TiO}_{2}$ nanoparticle was paste onto ITO glass using the doctor blade technique. The thickness and the area of the $\mathrm{TIO}_{2}$ on the surface of ITO glass will be control by two parallel adhesive tapes $1 \mathrm{~cm}$ apart and the area of the $\mathrm{TiO}_{2}$ film is $1.8 \times 1.0 \mathrm{~cm}$ before heated in the oven for 24 hours at $450{ }^{\circ} \mathrm{C}$. The dried $\mathrm{TiO}_{2}$ film was then immersed in varied $w \mathrm{t} \%$ of QDs for 24 hours in dark environment. Lastly, ethanol was used to remove and wash dye residue on the surface before dried again in the oven at $60^{\circ} \mathrm{C}$ for 24 hours

\subsection{Characterization of N719/CdSe-ZnS solution}

\subsubsection{X-ray diffraction technique (XRD)}

XRD was used to study the crystalline structure and phase components of QDs powder. The structure spacing was determined by the high of intensity peak of the spectra. The higher number of count on the same angle prove that the existing components of the CdSe and $\mathrm{ZnS}$.

\subsubsection{Uv-vis spectrometry}

$\mathrm{UV}-\mathrm{Vis}$ spectrometry uses to detect the band gap of each sample in the form of a solution. $0.0005 \mathrm{mM} \mathrm{CdSe} / \mathrm{ZnS}$ was analyzed at a range of $200-900 \mathrm{~nm}$ and the blank solution is ethanol.

$$
E=h(c / \Lambda)
$$

\subsection{Characterization ITO/TiO $/$ /N719/CdSe-ZnS photoanode}

\subsubsection{Cyclic voltammetry}

The conductivity of co-sensitized of photoanode were be analyzed using the Cyclic voltammetry device. The sample of difference $\mathrm{wt} \%$ of QDs $\left(\mathrm{ITO} / \mathrm{TiO}_{2} / \mathrm{N} 719\right.$ $\mathrm{CdSe} / \mathrm{ZnS}$ ) photoanode were used as a working electrode $\left(\mathrm{W}_{\mathrm{e}}\right)$, while the counter electrode $\left(\mathrm{C}_{\mathrm{e}}\right)$ is platinum and $\mathrm{Ag} / \mathrm{AgCI} / 3 \mathrm{MKCI}$ was act as the reference electrode. The applied voltage on the sample was from $-1.0 \mathrm{~V}$ to $1.0 \mathrm{~V}$ and every sample was run for three cycles to get the average data [11]

\section{Results and Discussions}

Figure 1 shows the proof of the existing component $\mathrm{CdSe}$ and $\mathrm{ZnS}$ in the sample powder. From the result in Figure la the experiment stick pattern of $\mathrm{ZnS}$ and $\mathrm{CdSe}$ is similar to the reference stick pattern from Institute of Chemical Dependency Studies (ICSD) by xu,y-N ching (1993). The h,k,l peak of CdSe which is(100) is the first clearly produce in the experimental result and another peak such as 002,101,102 also clearly be observed between this two pattern. In Table 2 the first three peak produce at 23.881,25.381,27.101 which is 100,002 and 101 show the strongest proof that this powder is CdSe.

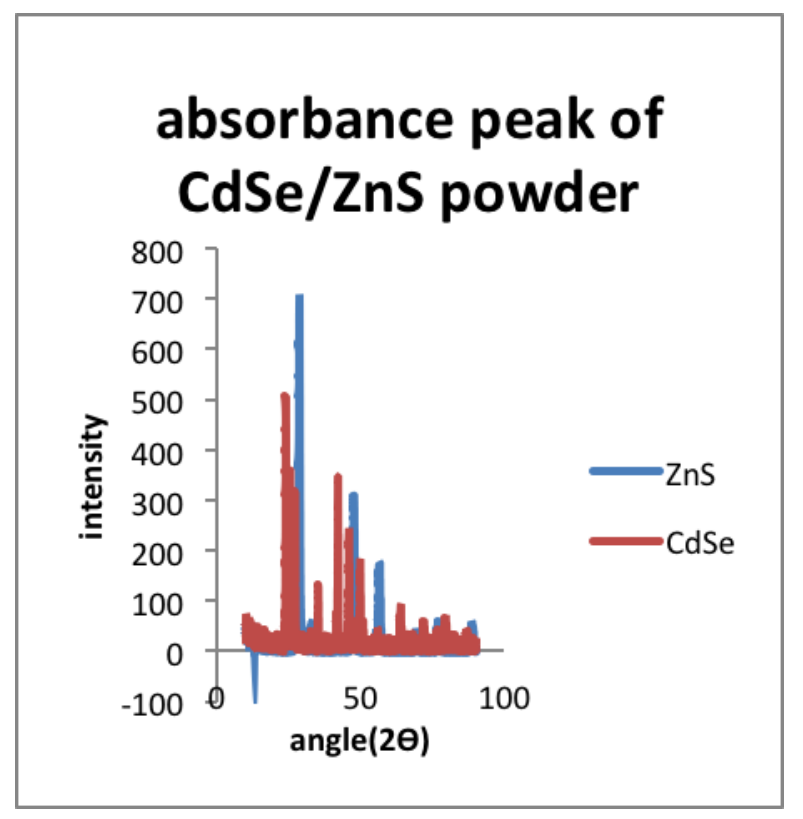

Fig. 1(a). Experimental absorbance peak CdSe/ZnS QDs 


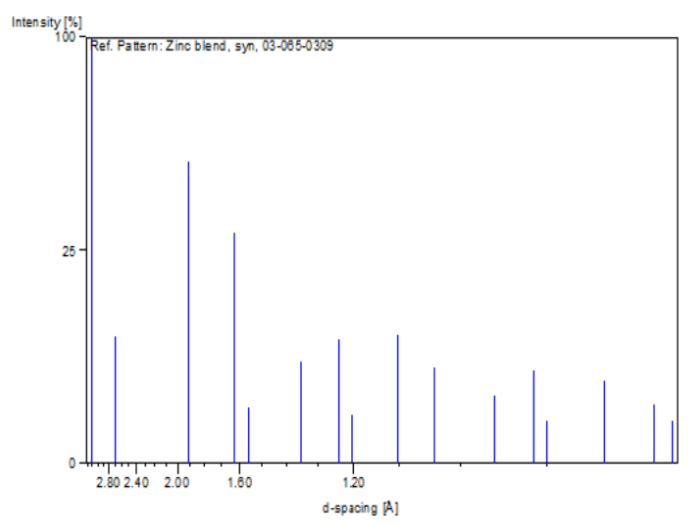

Fig. 1(b): Absorbance Opeak of CdSe QDs

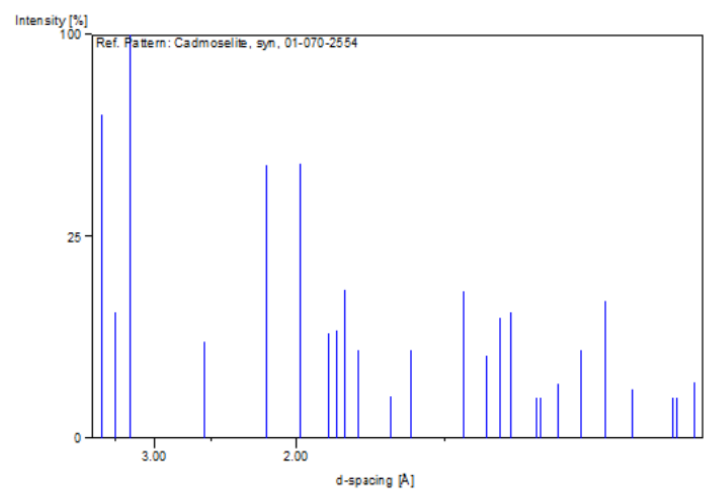

Fig. 1(c): Absorbance Opeak of ZnS QDs

Table 2. Comparison reference (R) result and experimental (Ep) result of CdSe powder

\begin{tabular}{|c|c|c|c|c|c|c|c|}
\hline No & $\mathrm{h}$ & $\mathrm{k}$ & 1 & $\begin{array}{c}(\mathrm{R}) \\
2 \Theta\end{array}$ & $\begin{array}{c}(\mathrm{R}) \\
\mathrm{d}(\mathrm{A})\end{array}$ & $\begin{array}{c}(\mathrm{Ep}) \\
2 \Theta\end{array}$ & $\begin{array}{c}(\mathrm{Ep}) \\
\mathrm{d}(\mathrm{A})\end{array}$ \\
\hline 1 & 1 & 0 & 0 & 23.882 & 3.723 & 23.881 & 3.726 \\
\hline 2 & 0 & 0 & 2 & 25.373 & 3.507 & 25.381 & 3.509 \\
\hline 3 & 1 & 0 & 1 & 27.093 & 3.288 & 27.101 & 3.290 \\
\hline 4 & 1 & 0 & 2 & 35.123 & 2.552 & 35.129 & 2.554 \\
\hline
\end{tabular}

Table 3. Comparison reference (R) result and experimental(Ep) result of $\mathrm{ZnS}$ powder

\begin{tabular}{|c|c|c|c|c|c|c|c|}
\hline No & $\mathrm{h}$ & $\mathrm{k}$ & $\mathrm{l}$ & $\begin{array}{c}(\mathrm{R}) \\
2 \Theta\end{array}$ & $\begin{array}{c}(\mathrm{R}) \\
\mathrm{d}(\mathrm{A})\end{array}$ & $\begin{array}{c}(\mathrm{EP}) \\
2 \Theta\end{array}$ & $\begin{array}{c}(\mathrm{EP}) \\
\mathrm{d}(\mathrm{A})\end{array}$ \\
\hline 1 & 1 & 1 & 1 & 28.609 & 3.117 & 28.589 & 3.122 \\
\hline 2 & 2 & 0 & 0 & 33.153 & 2.700 & 33.157 & 2.702 \\
\hline 3 & 2 & 2 & 0 & 47.591 & 1.909 & 47.581 & 1.911 \\
\hline 4 & 3 & 1 & 1 & 56.473 & 1.628 & 56.441 & 1.630 \\
\hline
\end{tabular}

In table3 the first three peak is at the angle $28.589^{\circ}, 33.157^{\circ}$ and $47.581^{\circ}$ which is the h,k,l peak is 111,200 and 220 , this peak is similar to the reference result from NIST by Dubrovin in 1983.

The highest number of count (intensity) by the CdSe samples is 505 at the angle 23.881, this means that the 505 particles reflects the $\mathrm{x}$-ray source to that detector at this angle and from calculation the spacing particle is 3.72651(A), this is the spacing between particles $d(A)$ in the CdSe powder that has been analyzed using XRD method compared to the reference result found that the spacing between the particle is 3.72304 (A) and their percentage difference is about $0.046 \%$.The very small percentage difference between reference $d(A)$ and sample $\mathrm{d}(\mathrm{A})$ prove that the powder consists the component of $\mathrm{CdSe}$. For the $\mathrm{ZnS}$ powder, the same method is used by comparing the difference between the spacing particle $d(A)$ in the sample with the reference result. The highest peak produce in the $\mathrm{ZnS}$ sample is 711 count at $28.569^{\circ}$ and the spacing between particle is about 3.12264(A), compared to the reference result the highest number count is at $28.609^{\circ}$ with the spacing between particles is 3.11769(A). The difference particle spacing between the reference value and $\mathrm{ZnS}$ sample is $0.0079 \%$, the small difference percentage prove that this powder is $\mathrm{ZnS}$. Table 2 and Table 3 shows the reference (R) and experiment (Ep) peak with comparison of the spacing between first four peaks.

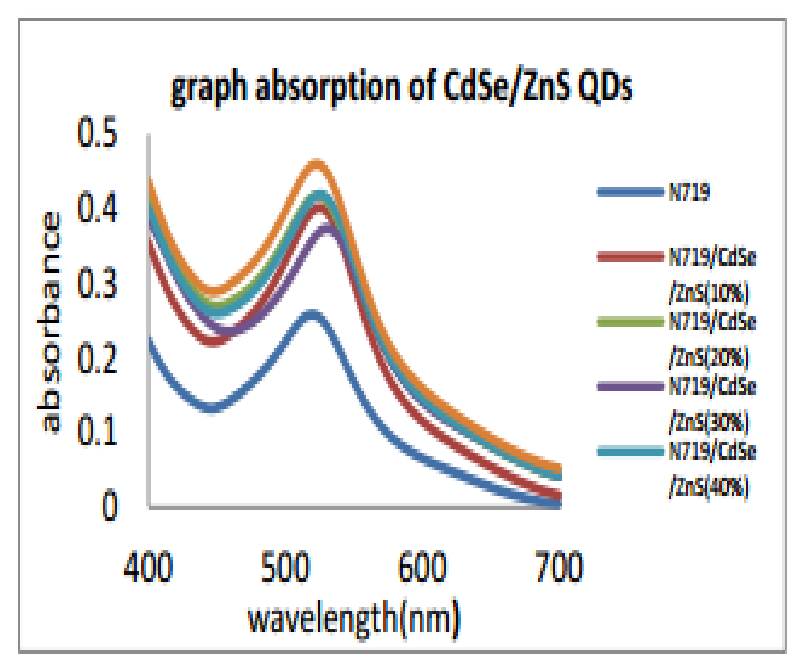

Figure 2. Graph absorption of CdSe/ZnS QDs

Table 4: The value absorbance of $\mathrm{CdSe} / \mathrm{ZnS}$ QDs with difference weight present ( $w \mathrm{t} \%$ )

\begin{tabular}{|c|c|c|c|c|c|c|}
\hline $\begin{array}{c}\text { Maxi } \\
\text { mum } \\
\text { wavel } \\
\text { ength } \\
(\mathrm{nm})\end{array}$ & $\mathrm{N} 719$ & $\begin{array}{c}\mathrm{N} 719 / \mathrm{C} \\
\mathrm{dSe} / \mathrm{Zn} \\
\mathrm{S}\end{array}$ & $\begin{array}{c}\mathrm{N} 719 / \\
\mathrm{CdSe} / \\
\mathrm{ZnS} \\
(10 \%)\end{array}$ & $\begin{array}{c}\mathrm{N} 719 / \\
\mathrm{CdSe} \\
/ \mathrm{ZnS} \\
(30 \%)\end{array}$ & $\begin{array}{c}\mathrm{N} 719 / \\
\mathrm{CdSe} \\
/ \mathrm{ZnS} \\
(40 \%)\end{array}$ & $\begin{array}{c}\mathrm{N} 719 / \\
\mathrm{CdSe} \\
/ \mathrm{ZnS} \\
(50 \%)\end{array}$ \\
\hline 525 & 0.2541 & 0.4015 & 0.4173 & 0.3687 & 0.4186 & 0.4584 \\
& & & & & & \\
\hline
\end{tabular}

Figure 2 shows the spectra absorption of six samples with various $\mathrm{wt} \%$. The highest peak of spectra is $525 \mathrm{~nm}$ of wavelength. This shows that the electron in the sample needs the energy of light with $525 \mathrm{~nm}$ to excited one electron out of the particle. Equation 4 was used to calculate the band gap of the $\mathrm{CdSe} / \mathrm{ZnS}$ resulted $2.36 \mathrm{eV}$.

However, control variable, N719 dye showed the absorbance peak at 0.2541 as tabulated in Table 4 . As for $10 \mathrm{wt} \% \mathrm{CdSe} / \mathrm{ZnS}$ QDs, the absorbance peak shifted from 0.2541 to 0.4015 . This result shows that the combination of N719 and CdSe/ZnS QDs can increase the absorption of light. The $20 \% \mathrm{ZnS}$ sample have the higher absorbance peak compared to the $10 \% \mathrm{ZnS}$ sample. The difference between this two peak is $2 \%$ may due to formation hole in the $20 \% \mathrm{ZnS}$ sample is higher compared to the $10 \mathrm{wt} \%$ 
$\mathrm{ZnS}$. The absorbance peak of $20 \mathrm{wt} \% \mathrm{ZnS}$ is higher compared to $30 \mathrm{wt} \% \mathrm{ZnS}$ samples. The absorbance peak of $40 \mathrm{wt} \% \mathrm{ZnS}$ sample higher than $20 \mathrm{wt} \% \mathrm{ZnS}$ sample. The absorbance peak of $50 \mathrm{wt} \% \mathrm{ZnS}$ is higher compared

$3 a$

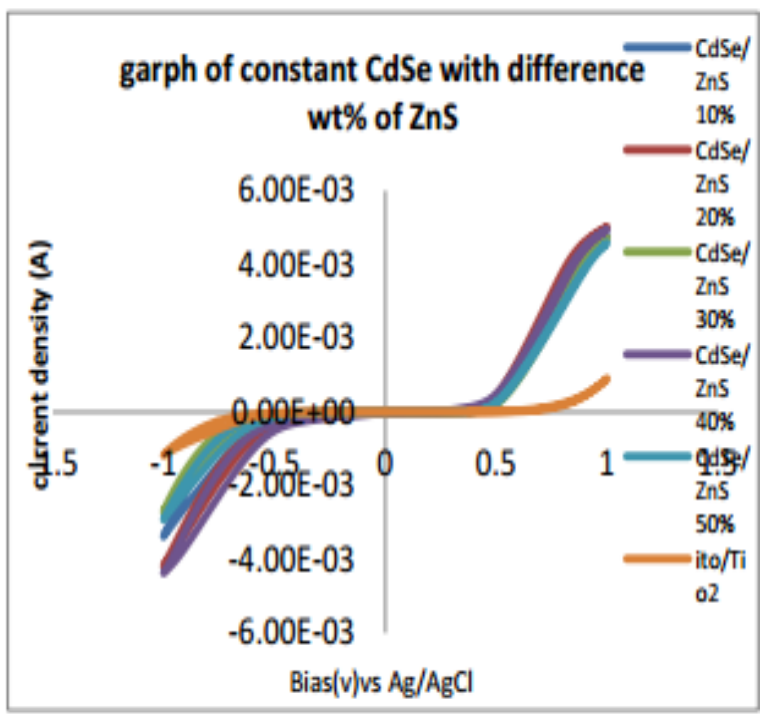

$3 c$

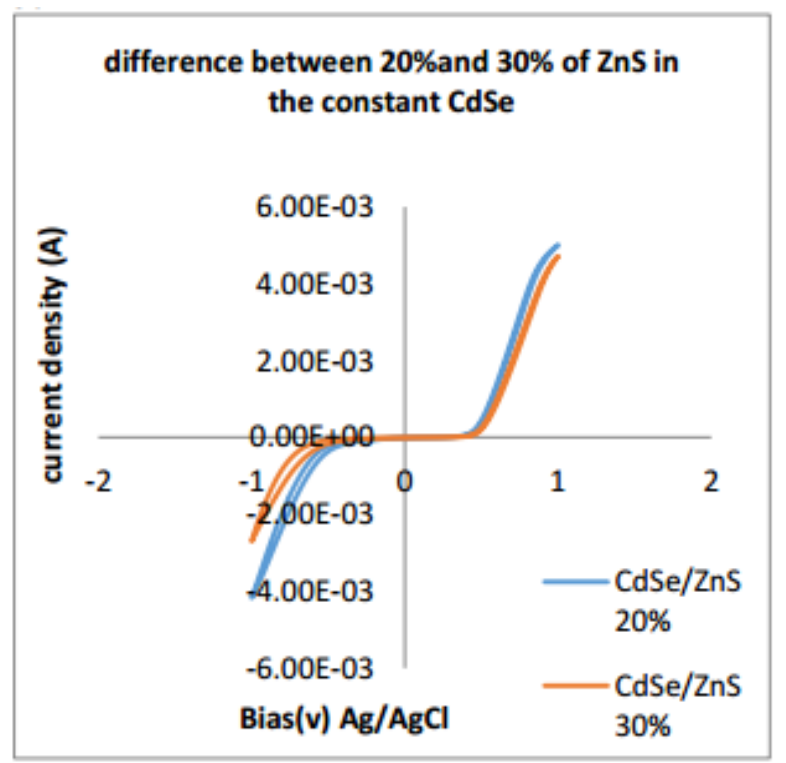

to $40 \mathrm{wt} \% \mathrm{ZnS}$ sample, this shows that the most suitable material to increase the absorption process is $50 \mathrm{wt} \%$ of $\mathrm{ZnS}$.

$3 b$

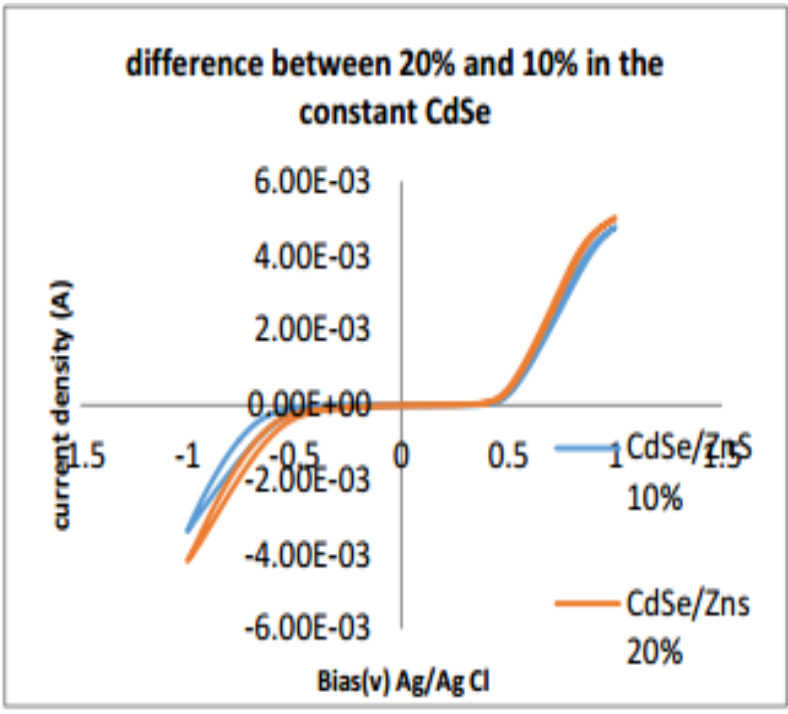

$3 d$

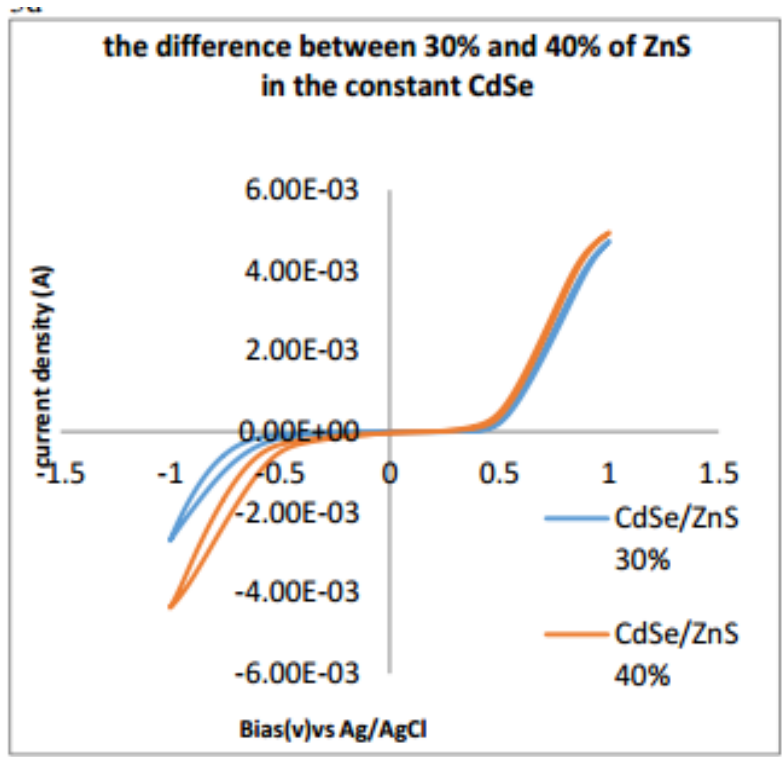


$3 e$

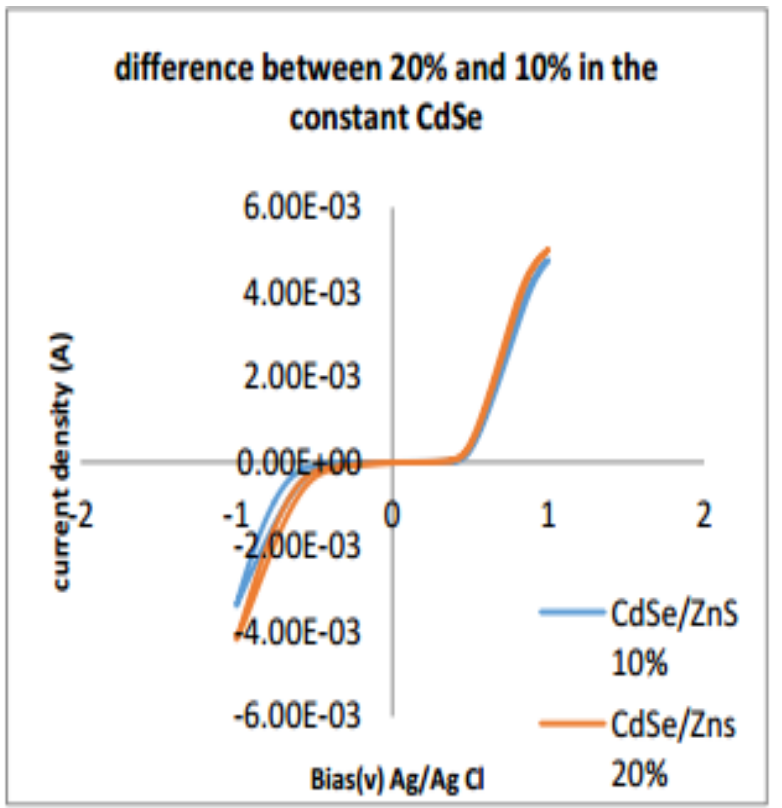

$3 \mathrm{f}$

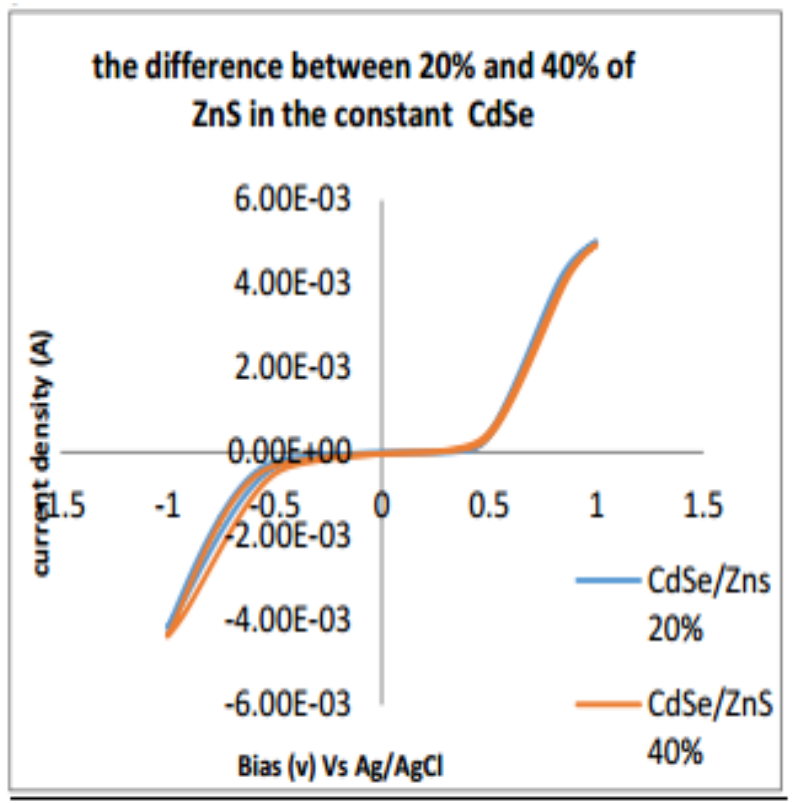

Fig. 3. Cyclic voltammetry of difference wt $\%$ of QDs

The I-V behavior of different sample with difference $\mathrm{wt} \%$ of $\mathrm{ZnS}$ QD showed in Figure 3. Figure 3a shows the comparison of current produced between sample photoanode with difference wt\% QD and sample without QDs. ITO/ $/ \mathrm{TiO}_{2}$ shows -0.00118 A while the combination of $\mathrm{ITO} / \mathrm{TiO}_{2} / \mathrm{CdSe}-\mathrm{ZnS}(10 \%)$ is $-0.00338 \mathrm{~A}$, gives the difference of $0.00220 \mathrm{~A}$. The current produced by the movement of an electron in the circuit, the more electrons flow the more current was produced [4]. However, the current from $\mathrm{TiO}_{2}$ photoanode in Figure 3a is low may be due to the structure of the material which have a medium recombination process [6]. This recombination process reduces the acceleration of the electron to move from one particle to another in the structure of the $\mathrm{TiO}_{2}$ thin film. Hence, the QDs photoanode consists of CdSe/ ZnS QDs provide a lot of hole at the valence shell of the particle, this valence shell is known as the hole act as the platform for the electron to jump from one particle to other until it reaches the conducting side of ITO glass [4]. The combination of $\mathrm{ITO} / \mathrm{TiO}_{2}$ with $\mathrm{CdSe} / \mathrm{ZnS}$ QDs could increase the total number of the hole. As the result, the electron could flow easily.

Figure $3 \mathrm{~b}$ shows the tabulated data of $10 \mathrm{wt} \%$ and $20 \mathrm{wt} \%$ of $\mathrm{ZnS}$. The current produce in $\mathrm{CdSe} / \mathrm{ZnS}$ (20 $w t \%)$ is higher compared to the CdSe/ZnS(10 wt $\%)$. The $20 \mathrm{wt} \% \mathrm{ZnS}$ produces $-0.00418 \mathrm{~A}$ of current while the 10 $\mathrm{wt} \%$ of $\mathrm{ZnS}$ is $-0.00337952 \mathrm{~A}$ the difference between this two sample is $-0.000801 \mathrm{~A}$.
Table 5. The maximum current produced in each sample

\begin{tabular}{|c|c|c|c|}
\hline Sample & $\begin{array}{c}\text { Applied } \\
\text { voltage (v) }\end{array}$ & $\begin{array}{c}\text { Current } \\
\text { produce (A) }\end{array}$ & $\begin{array}{c}\text { The } \\
\text { difference } \\
\text { current (A) } \\
\text { between Tio2 } \\
\text { and } \\
\text { QDs(wt } \%)\end{array}$ \\
\cline { 1 - 3 } ITO/TIO2 & -1.00098 & -0.00118 & -0.00220 \\
ITO/TIO2/ & -1.00098 & -0.00338 & \\
N719/CdSe- \\
ZnS(10\%) & & & -0.00300 \\
\cline { 1 - 2 } ITO/TIO2/ & -1.00098 & -0.00418 & -0.00152 \\
N719/CdSe- & & & \\
\hline $\begin{array}{c}\text { ITO/TIO2/ } \\
\text { N719/CdSe- } \\
\text { ZnS(30\%) }\end{array}$ & -1.00098 & -0.0027 & -0.00319 \\
\hline $\begin{array}{c}\text { ITO/TIO2/ } \\
\text { N719/CdSe- } \\
\text { ZnS(40\%) }\end{array}$ & -1.00098 & -0.00437 & \\
\hline $\begin{array}{c}\text { ITO/TIO2/ } \\
\text { N719/CdSe- } \\
\text { ZnS(50\%) }\end{array}$ & -1.00098 & -0.00292 & -0.00174 \\
\hline
\end{tabular}

The process of reduction in the system involved the donation of electrons from the electrolyte $(\mathrm{Ag} / \mathrm{AgCl} 1 \mathrm{M}$ $\mathrm{KCI})$ to the photoanode (CdSe/ZnS, QDs). The unstable particle which has the hole on their valence particle produce the easy way for an electron to pass through the barrier [6]. Table 5, shows the maximum current value produced by each sample. The highest value of current produced is $\mathrm{CdSe} / \mathrm{ZnS}(40 \mathrm{wt} \%$ ) which is $-0.00437 \mathrm{~A}$. The lowest current produce for the QDs photoanode is $\mathrm{CdSe} / \mathrm{ZnS}(10 \%)$. The current increase $-0.0008 \mathrm{~A}$ from 10 wt $\%$ to $20 \mathrm{wt} \%$ and -0.00167 from $30-40 \mathrm{wt} \%$ but the 
current reduce- 0.00148 A from $20 \mathrm{wt} \%$ to $30 \mathrm{wt} \%$ and $0.00145 \mathrm{~A}$ from $40 \mathrm{wt} \%$ to $50 \mathrm{wt} \%$ of $\mathrm{CdSe} / \mathrm{ZnS}$.

\section{Conclusions}

CdSe/ZnS QDs immersed in N719 could increase the movement of electrons in the photoanode materials. 50 $\mathrm{wt} \%$ of $\mathrm{ZnS}$ is the best composition to increase the absorbance peak of the photoanode. The Cyclic voltammetry $(\mathrm{CV})$ of varying $\mathrm{wt} \%$ of $\mathrm{ZnS}$, found that the $40 \mathrm{wt} \%$ of $\mathrm{ZnS}$ at $0.00437 \mathrm{~A}$ is suitable combination to make a photoanode and could produce the highest current.

Authors would like to thank Ministry of Higher Education (MOHE) Malaysia for funding this research under the FRGS/1/2015/SG06/UITM grant and Universiti Teknologi MARA (UiTM) for the facilities provided

\section{References}

1 D. Riehm,. Improving Dye-Sensitized Solar Cell Efficiency by Modification of Electrode Surface Charge.

2 Z. Li, Y.Xie, H.Xu, T.Wang, Z.Xu, \& H.Zhang,. Journal of Photochemistry and Photobiology A : Chemistry Expanding the photoresponse range of TiO 2 nanotube arrays by CdS / CdSe / ZnS quantum dots co-modification. "Journal of Photochemistry \& Photobiology, A: Chemistry, (2011).

3 K.Kim, J.Eun, E.Su, Y.Chang, J.Kim, C.Im, \& M.Lee,. Electrochimica Acta ZnS-Passivated CdSe / CdS Co-sensitized Mesoporous Zn $2 \mathrm{SnO} 4$ Based Solar Cells. (2014).
4 P. V.Kamat,. Quantum Dot Solar Cells . Semiconductor Nanocrystals as Light(2008) .

5 A.Undergraduate,. Optical Properties of Quantum Dots : An Undergraduate Physics Laboratory,(2007).

6 B. I.Photovoltaics,. 2 Dye sensitized solar cells (DSSC), (n.d.).

7 B. O.Dabbousi, F. V Mikulec, J. R.Heine, H.Mattoussi, R.Ober, K. F.Jensen, \& M. G.Bawendi.. ( CdSe ) ZnS Core - Shell Quantum Dots : Synthesis and Characterization of a Size Series of Highly Luminescent Nanocrystallites(1997).

8 I.Mora-Seró, V.Likodimos, S.Giménez, E.MartínezFerrero, J.Albero, E.Palomares, J.Bisquert, Fast Regeneration of CdSe Quantum Dots by Ru Dye in Sensitized TiO2 Electrodes. The Journal of Physical Chemistry C, 6755-6761, (2010).

9 M. A. M.Al-Alwani, A. B.Mohamad, N. A.Ludin, A. A. H.Kadhum, \& K.Sopian,. Dye-sensitised solar cells: Development, structure, operation principles, electron kinetics, characterisation, synthesis materials and natural photosensitisers. Renewable and Sustainable Energy 183-213,(2016).

10 M. L.Landry, T. E.Morrell, T. K.Karagounis, C. H.Hsia, \& C. Y Wang,. Simple syntheses of CdSe quantum dots. Journal of Chemical Education, 274279. (2014).

11 E. M.Boatman, G. C.Lisensky, \& K. J.Nordell, A Safer , Easier , Faster Synthesis for CdSe Quantum Dot Nanocrystals, 82(11), 1697-1699, (2005).

12 E.Bayatloo, \& E.Saievar-iranizad,Dye-sensitized solar cells by carbon nanospheres in photoanode. 